University of Maryland Francis King Carey School of Law

DigitalCommons@UM Carey Law

2010

\title{
Mothers, Domestic Violence and Child Protection: An American Legal Perspective
}

\author{
Leigh S. Goodmark \\ University of Maryland Francis King Carey School of Law, Igoodmark@law.umaryland.edu
}

Follow this and additional works at: https://digitalcommons.law.umaryland.edu/fac_pubs

Part of the Law and Gender Commons

\section{Digital Commons Citation}

16 Violence Against Women 524 (2010).

This Article is brought to you for free and open access by the Francis King Carey School of Law Faculty at DigitalCommons@UM Carey Law. It has been accepted for inclusion in Faculty Scholarship by an authorized administrator of DigitalCommons@UM Carey Law. For more information, please contact smccarty@law.umaryland.edu. 


\title{
Violence Against Women \\ http://vaw.sagepub.com/
}

\section{Mothers, Domestic Violence, and Child Protection: An American Legal Perspective \\ Leigh Goodmark \\ Violence Against Women 2010 16: 524 \\ DOI: $10.1177 / 1077801210366290$}

The online version of this article can be found at:

http://vaw.sagepub.com/content/16/5/524

\author{
Published by: \\ (S)SAGE \\ http://www.sagepublications.com
}

Additional services and information for Violence Against Women can be found at:

Email Alerts: http://vaw.sagepub.com/cgi/alerts

Subscriptions: http://vaw.sagepub.com/subscriptions

Reprints: http://www.sagepub.com/journalsReprints.nav

Permissions: http://www.sagepub.com/journalsPermissions.nav

Citations: http://vaw.sagepub.com/content/16/5/524.refs.html

>> Version of Record - Apr 13, 2010

What is This? 
Mothers, Domestic Violence, and Child

Protection: An American

Legal Perspective
Violence Against Women

16(5) 524-529

(C) The Author(s) 2010

Reprints and permission: http://www. sagepub.com/journalsPermissions.nav DOI: $10.1177 / 1077801210366290$ http://vaw.sagepub.com

@SAGE

\title{
Leigh Goodmark'
}

\author{
Keywords \\ child protection, domestic violence, law, U.S. legal system
}

In their article, "Mothers, Domestic Violence, and Child Protection," Heather Douglas and Tamara Walsh explore the problematic treatment of battered mothers by the child protection system in Brisbane, Australia. Their study documents a number of troubling trends, including mother blaming for failure to protect, inappropriate removals of children from protective mothers, placement of children with fathers who had battered their partners, and the ill-advised "leaving ultimatum" - the order that a mother who has been battered leave her abusive partner to show her intention to protect her children from further exposure to violence. These trends are not unique to the Australian child protection system. Numerous commentators have documented similar issues in the child protection system in the United States - problems that, to some degree, are created and exacerbated by statutes, case law, and practice.

\section{State Laws on Child Abuse and Neglect}

As in Australia, states incorporate domestic violence in their child protection statutes in a number of ways. In some states, the law mandates that a child's exposure to domestic violence be reported to child protective services. Other states include domestic violence in their definitions of child abuse or neglect or in their statutes outlining the types of cases over which the dependency court has jurisdiction (Weithorn, 2001). Defining exposure to domestic violence as abusive or neglectful in state child abuse and neglect statutes and case law contributes to the punitive climate Douglas and Walsh explore in their article.

'University of Baltimore School of Law

\section{Corresponding Author:}

Leigh Goodmark, University of Baltimore School of Law, 5 West Chase Street, Baltimore, MD 2I 20 I

E-mail: lgoodmark@ubalt.edu 
The choices that child protection workers make are shaped by legal mandates triggered when an allegation of abuse or neglect is made. Defining exposure to domestic violence as abuse and/or neglect forces child protection workers to respond to cases involving domestic violence as though children are at immediate risk of harm. Workers then employ the tools available to them in such situations, including removal of the child. Actions perceived as hostile by mothers who have been battered and their advocates may, in fact, be compelled by agency policy and procedure; once exposure is defined as abusive and/or neglectful, workers may have very little leeway in their dealings with the mother and her children.

Defining exposure to domestic violence as abusive or neglectful also colors the ways in which child protection workers view mothers who experience violence. Law serves more than a regulatory function; it operates to express the prevailing beliefs and mores of a society. When exposure to violence is automatically equated with abuse or neglect, it is far easier to see mothers who have experienced violence as abusive and neglectful, as acting purposefully to expose their children to violence. In a system that defines its mission as protecting children rather than strengthening families, parents are necessarily cast as the enemy, particularly parents who do not act as professionals expect them to act. The combination of legal structure and myths about domestic violence and about women who experience domestic violence combine to create a mindset among child protection professionals that sets mothers in opposition to their children.

This is not to argue that exposure to domestic violence can never be considered abusive or neglectful. Exposure to domestic violence can be harmful to children. When exposure to a parent's battering is causing harm to a child, and the abused parent is unable or unwilling to do anything to ameliorate that harm, intervention by the child welfare system may be appropriate. What form that intervention should take depends on a number of factors, including the type of harm the child experiences, the availability of resources to help keep the abused parent and child safe, and the willingness of the abused parent to work with child welfare professionals to protect the child from further exposure. But exposure to domestic violence need not be defined as per se harmful for this type of intervention to happen. Existing definitions of child abuse and neglect permit child welfare professionals to intervene whenever they can show actual or serious potential harm to a child. To determine whether actual or serious potential harm exists, caseworkers must investigate the family context. Along the way, the caseworker might develop a relationship with and an understanding of the strengths of the nonabusive parent.

Such an investigation need never take place, however, if domestic violence is defined as per se abuse or neglect. Defining exposure to domestic violence as abusive or neglectful colors the relationship from its inception and necessarily changes the nature of the response. Using the harm provisions rather than labeling victimized parents as abusive or neglectful might help to change the perceptions of child welfare professionals and decrease the hostility perceived by mothers who experience domestic violence.

\section{Nicholson v. Williams}

Advocates for women who had been battered hoped that Nicholson v. Williams (2002) would change the legal landscape for women who experienced violence and found themselves 
enmeshed in the child welfare system. In Nicholson, a class of battered mothers and their children challenged New York City's Administration for Children Services' (ACS) policy of removing children from homes and instituting dependency proceedings against mothers who had exposed their children to domestic violence by being victimized in their presence, without showing harm to the child or considering the context within which that exposure took place. The results of that policy were, in some cases, ludicrous. Sharwline Nicholson, the named plaintiff, was brutally beaten by her daughter's father after she told him of her intention to end the relationship. Her daughter was in her crib in another room during the attack; her son was at school. Bleeding profusely, Ms. Nicholson arranged for her children's babysitter to care for them as she was waiting to be taken to the hospital. Nonetheless, ACS removed the children from the babysitter's home, alleging that Ms. Nicholson was unable to protect her children as a result of the assault upon her. Ms. Nicholson was not reunited with her children for 21 days, 14 days after the family court ordered that her children be returned to her custody. The U.S. District Court for the Eastern District of New York found that incidents such as this one constituted an unconstitutional infringement on mothers' and children's due process rights. The court prohibited ACS from removing children from their mothers solely because those children had been exposed to domestic violence.

Nicholson was hailed as a watershed decision; for the first time, and in an incredibly powerful opinion, a federal court had found that battered mothers could not constitutionally be held responsible for the acts of their abusers. Advocates hoped that Nicholson would change the practices of child welfare agencies nationwide that continued to remove children from nonoffending mothers as a result of exposure to domestic violence.

Indeed, a few courts have followed Nicholson in finding that child welfare agencies and courts cannot assume harm as a result of exposure to domestic violence; battered mothers can only be held responsible for the failure to exercise some degree of care in protecting their children from the violence (Dunlap, 2005). But some commentators have lamented Nicholson's limited reach. Child welfare agencies in New Jersey and Florida continue to remove children from battered parents under the assumption that children are harmed by exposure (Clarke, 2006). One court has cited Nicholson to support the proposition that exposure to domestic violence necessarily causes harm to the child (Dunlap, 2005). Even the review panel instituted to monitor ACS's compliance with the Nicholson decision found that ACS continues to bring children into the system as a result of exposure to domestic violence, albeit using other pretextual grounds to institute cases against the mothers (Stark, 2005).

\section{The Leave Ultimatum}

Douglas and Walsh discuss what they call the leave ultimatum: the demand from caseworkers that mothers either end their relationships with their abusive partners or lose their children. Child protection workers in the United States make the same pronouncements, sometimes with the force of law behind them. In the District of Columbia, for example, filing for a civil protection order is considered proof that the mother has made "reasonable efforts" to prevent the child from being abused or neglected as a result of exposure to 
violence. This provision was added to the law in response to the concerns of advocates that mothers who experienced domestic violence were being targeted by child protection workers. What that provision does, though, is send the message that a protective mother is a mother who seeks the legal system's assistance in separating from her partner. Failure to seek a protective order can then be equated with failure to protect. In a system that overvalues leaving, it is not surprising that after the Nicholson decision, ACS charged several mothers with neglect for failing to obtain or serve protection orders on their abusive partners (Stark, 2005).

The irony, of course, is that seeking the protection of the legal system is no guarantee of safety for a woman who has been battered or her children. In fact, seeking the protection of the legal system does not even guarantee that a woman will be perceived as protective. Judges hearing protective orders have been known to make reports to child protective services from the bench, despite the presence before them of women seeking protection and safety. One judge in Pennsylvania denied a mother's request for a protective order on behalf of her children, a remedy available under Pennsylvania law. Instead, the judge removed the children from the mother's custody and immediately placed them in foster care (Goodmark, 2004).

The leave ultimatum as embodied in the direction to obtain a protective order makes a number of assumptions: that the woman can get an order, that the order will provide relief that will keep her abuser away, and that her partner will comply with the order. If any of those conditions is not met, the mother, despite her best efforts to meet the expectations of child protective workers, may find herself at odds with the child welfare system. A substantial likelihood exists, however, that one or more of those conditions will not be met. Service of process is required to effectuate a protective order, but abusive partners often do not want to be found. In the courts of Baltimore, Maryland, for example, case after case is continued for lack of service of process, resulting in frustration and anger for women who return to court repeatedly, only to be told that they cannot be helped. Judges are not always willing to grant the orders, and if they do, they are not always willing to order the requested relief. Getting an abusive partner removed from the family home can be particularly difficult; in one case in the District of Columbia, a judge allowed a woman's partner to remain in the basement of their home, where he continued to terrorize the family from below. She was forced to return to court to beg for his removal. Child protection workers sometimes equate the failure to secure a protective order, or the failure to obtain an order with particular provisions, with lack of effort on the part of the mother, as documented by the Nicholson review panel. As Evan Stark (2005), a member of that panel, writes, "The expectation that women will follow certain steps-even if there is no evidence these steps are likely to be more effective than other steps - is a common foundation for the punitive responses to battered mothers" (p. 706). Once she has the order, a mother who has been battered is then expected to enforce that order, which requires her to control two entities over whom she has no control-her partner and the police. The woman who has been abused cannot ensure that her partner will not contact her or her children, nor can she ensure that the police will come to enforce the order if she calls. The failure to do either, though, could constitute evidence 
that she is failing to protect her children from exposure to abuse. Even for women who do attempt to leave, then, satisfying the leave ultimatum can be difficult at best, impossible at worst.

\section{Conclusion}

Douglas and Walsh make a number of suggestions for improving relationships between child protection workers and domestic violence advocates. They posit that enhanced criminal justice interventions could help alleviate the tension between child protection and mothers who have been battered. The well-developed and well-funded criminal justice response in the United States has not made for improved relationships between mothers and child protection, however, and the data on the value of those interventions in decreasing domestic violence and better protecting women who have been battered are equivocal at best (Goodmark, 2009). Douglas and Walsh also advocate for better education and supervision of child protection workers; similar proposals have been made in the United States and have been implemented with some measure of success (ICF International, 2008). But focusing primarily on changing the institutional culture of child protection will not be sufficient to fundamentally alter the way in which child protection workers interact with mothers who have experienced domestic violence. Until the law and the legal system reflect an understanding of domestic violence, and of the barriers faced by mothers seeking to protect their children from domestic violence, real change will be difficult, if not impossible, to achieve.

\section{Declaration of Conflicting Interests}

The author declared no potential conflicts of interest with respect to the authorship and/or publication of this article.

\section{Funding}

The author received no financial support for the research and/or authorship of this article.

\section{References}

Clarke, S. N. (2006). Strictly liable: Governmental use of the parent-child relationship as a basis for holding victims liable for their child's witness to domestic violence. Family Court Review, 44, 149-159.

Dunlap, J. A. (2005). Judging Nicholson: An assessment of Nicholson v. Scoppetta. Denver University Law Review, 82, 671-689.

Goodmark, L. (2004). Law is the answer? Do we know that for sure? Questioning the efficacy of legal interventions for battered women. St. Louis University Public Law Review, 23, 7-48.

Goodmark, L. (2009). Autonomy feminism: An anti-essentialist critique of mandatory interventions in domestic violence cases. Florida State University Law Review, 37, 1-48.

ICF International. (2008). The Greenbook Initiative final evaluation report. Fairfax, VA: Greenbook National Evaluation Team.

Nicholson v. Williams, 203 F. Supp. 2d 153 (E.D.N.Y. 2002). 
Stark, E. (2005). Nicholson v. Williams revisited: When good people do bad things. Denver University Law Review, 82, 691-721.

Weithorn, L. A. (2001). Protecting children from exposure to domestic violence: The use and abuse of child maltreatment. Hastings Law Journal, 53, 1-153.

\section{Bio}

Leigh Goodmark is an associate professor, director of the Family Law Clinic, and codirector of the Center on Applied Feminism at the University of Baltimore School of Law. Her research focuses on the legal system's treatment of domestic violence. Her forthcoming book on that topic, A Troubled Marriage: Domestic Violence and the Legal System, will be published by New York University Press. 